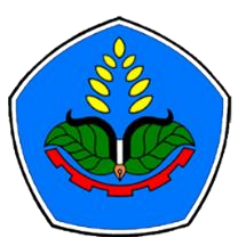

AGROPROSS

National Conference

Proceedings of Agriculture

\section{Conference:}

Implementasi IPTEKS Sub Sektor Perkebunan Pendukung

Devisa Negara dan Ketahanan Energi Indonesia

Tempat : Gedung Pascasarjana, Politeknik Negeri Jember

Tanggal : 18-19 September 2019

\section{Proceedings Series:}

Agropross : National Conference Proceedings of Agriculture

DOI : 10.25047/agropross.2019.90

\title{
Keputusan Petani Dalam Alih Komoditas Tanaman Tembakau Ke Sayuran (Studi Kasus Kecamatan Pegantenan Kabupaten Pamekasan)
}

\author{
Author(s): Yanti Nurmalasari*(1); Ruly Awidiyantini (1) \\ (1) Universitas Islam Madura, Indonesia \\ * Corresponding author:a15y14h@rocketmail.com
}

\begin{abstract}
This study aims to determine the factors that influence the behavior of farmers in switching crop commodities from tobacco farming to vegetable farming in Tlagah Village, Pegantenan District, Pamekasan Regency. The choice of location is determined intentionally (purposive), which is based on the consideration that many Tlagah villagers carry out land conversion from tobacco farming to vegetable farming. This study used a survey method with the population being all farmers who converted land from tobacco farming to vegetables. Determination of the sample in this study using a purposive sampling method. The analytical method uses LOGIT analysis using SPSS (Statistical Product and Service Solution) analysis tools. The results of this study note that the factors that influence the transfer of crop commodities are age, education level, farmer group participation, side jobs, and family dependents.
\end{abstract} Keyword:

Tobacco;

Vegetables;

LOGIT

Analysis;

\section{Kata Kunci: \\ Tembakau; \\ Sayuran;

Sayuran; \\ Analisis \\ LOGIT;}

ABSTRAK Penelitian ini bertujuan untuk mengetahui faktor-faktor yang mempengaruhi perilaku petani dalam alih komoditas tanaman dari usahatani tembakau menjadi usahatani sayur-mayur di Desa Tlagah Kecamatan Pegantenan Kabupaten Pamekasan. Pemilihan lokasi ditentukan secara sengaja (purposive), yaitu berdasarkan pertimbangan bahwa banyak masyarakat Desa Tlagah yang melakukan alih fungsi lahan dari usahatani tembakau ke usahatani sayur mayur. Penelitian ini menggunakan metode survey dengan populasinya adalah semua petani yang melakukan alih fungsi lahan dari usahatani tembakau menjadi sayur mayur. Penentuan sampel dalam penelitian ini menggunakan metode purposive sampling (sampel bertujuan). Metode analisis menggunakan analisis LOGIT dengan menggunakan alat analisis SPSS (Statistical Produk and Service Solution). Hasil dari penelitian ini diketahui bahwa faktor yang mempengaruhi alih komoditas tanaman adalah usia, tingkat pendidikan, keikutsertaan kelompok tani, pekerjaan sampingan, dan tanggungan keluarga. 


\section{PENDAHULUAN}

Lahan pertanian memiliki arti yang sangat penting dalam upaya memprertahankan ketahanan pangan. Namun seiring perkembangan zaman, pertambahan penduduk, dan tuntutan ekonomi, eksistensi lahan pangan mulai terusik. Salah satu permasalahan yang cukup serius saat ini berkaitan dengan lahan pangan adalah makin maraknya alih fungsi lahan dari suatu usahatani ke usahatani lainnya.

Kesejahteraan petani yang tidak semakin membaik semakin menjadi faktor pendorong terjadinya konversi lahan pertanian. Peningkatan taraf hidup menjadi alasan krusial yang tidak bisa ditolak ketika para petani atau pemilik lahan mengalih fungsikan lahan mereka menjadi lebih produktif dengan menanam tanaman sayur-mayur.

Kecamatan Pegantenan termasuk daerah yang memiliki lahan pertanian yang luas dan produktif. Terdapat beberapa jenis tanaman pertanian yang dihasilkan oleh petani Kecamatan Pegantenan, antara lain tembakau, buah buahan, jagung, sayursayuran, dan tanaman sawah/padi. Adanya masalah yang ditemui dalam sektor pertanian yaitu dalam tingkat pendapatan ekonominya. Petani terus berusaha untuk mengelola usahataninya dengan tujuan meningkatkan pendapatannya. Berbagai cara dilakukan oleh petani, salah satunya dengan mengubah pemanfaatan lahan usahataninya.

Diantara komoditas yang menjadi tulang punggung untuk memenuhi kebutuhan hidup masyarakat Tlagah adalah tembakau. Disamping penghasilan yang didapat dari tembakau sangat besar, juga karena hal ini sudah menjadi tradisi setiap tahun saat musim kemarau. Tanaman tembakau merupakan tanaman yang mempunyai potensi yang sangat besar di Desa Tlagah Kecamatan Pegantenan secara khusus dan masyarakat Madura secara umum. Karena tanaman tembakau mereka jadikan sebagai komoditas utama yang menjanjikan untuk memenuhi kebutuhannya.

Namun beberapa tahun terakhir ini, masyarakat Tlagah mengalami kegagalan yang beruntun dari tanaman tembakau mereka, dikarenakan adanya cuaca yang tidak stabil, yaitu adanya hujan yang intensif dengan curah hujan yang besar.

Disamping itu, tanaman sayur-mayur mengalami peningkatan, baik dari usahatani dan pemasarannya, karena sayurmayur merupakan tanaman yang dibutuhkan setiap hari. Banyak jenis tumbuhan sayur-mayur yang dapat ditanam pada saat musim hujan. Diantaranya adalah cabai, kangkung, dan lainnya. Sehingga dari kejadian ini, banyak masyarakat yang mulai beralih komoditas tanaman.

Sehingga dari berbagai masalah diatas banyak petani tembakau yang melakukan alih komoditas tanaman dari usahatani tembakau ke usahatani sayurmayur. Untuk itulah perlu diadakan sebuah kajian penelitian untuk mengetahui faktor apa saja yang mempengaruhi alih fungsi lahan di daerah tersebut.

Penelitian ini bertujuan untuk mengetahui faktor-faktor yang mempengaruhi perilaku petani dalam alih komoditas tanaman dari usahatani tembakau menjadi usahatani sayur-mayur di Desa Tlagah Pegantenan Pamekasan.

\section{METODE PENELITIAN}

Penelitian ini dilakukan di Desa Tlagah Pegantenan Kabupaten Pamekasan. Pemilihan lokasi ditentukan secara sengaja (purposive), dengan pertimbangan bahwa banyak masyarakat Desa Tlagah yang melakukan alih fungsi lahan dari usahatani tembakau ke usahatani sayur mayur.

Jenis data dalam penelitian ini meliputi dua sumber, yaitu data primer dan data sekunder. Data primer ini diperoleh dari responden yaitu petani yang melakukan alih fungsi lahan ke sayur 
mayur.dan data sekunder pada penelitian ini dapat diperoleh dari Dinas Tanaman Pangan dan Hortikultura Kabupaten Pamekasan dan Profil Desa Tlagah. Datadata tersebut diperoleh dengan menggunakan teknik pengamatan (observasi) dan wawancara (interview).

Analisis data yang digunakan untuk mengetahui faktor-faktor yang mempengaruhi alih fungsi lahan tembakau ke sayur mayur adalah dengan metode kuantitatif menggunakan analisis LOGIT dengan penggunaan aplikasi SPSS (Statistical Produk and Service Solution) dengan persamaan sebagai berikut :

$$
\begin{aligned}
& \mathrm{Y}=\alpha+\beta 1 \mathrm{X}+\beta 2 \mathrm{X} 2+\ldots . .+\beta \mathrm{iXi}+\mathrm{u} \ldots . . \\
& \text { Dimana }: \\
& \mathrm{Y} \quad \text { : Variabel terikat atau variable dependen } \\
& \mathrm{A} \quad \text { : Nilai konstanta yang akan diperoleh } \\
& \mathrm{Bi} \quad \text { : Koefisien regresi Xi } \\
& \mathrm{Xi} \quad \text { Variabel bebas } \\
& \mathrm{U} \quad \text { : Error } \\
& \mathrm{I} \quad \text { : Jumlah variable bebas }
\end{aligned}
$$

Sehingga model regresi berganda yang digunakan dalam model penelitian ini adalah :

$$
\mathrm{Y}=\alpha+\beta 1 \mathrm{X} 1+\beta 2 \mathrm{X} 2+\beta 3 \mathrm{X} 3+\beta 4 \mathrm{X} 4+\beta 5 \mathrm{X} 5+\mathrm{u}
$$

Dimana :

$\mathrm{Y}=0$ : Keputusan petani dalam mempertahankan tembakau.

$\mathrm{Y}=1 \quad$ : Keputusan mengkonversi lahan

$\mathrm{X} 1 \quad$ : Faktor usia

X2 : Faktor tingkat pendidikan

X3 : Keikut sertaan kelompok tani

X4 : Tingkat pekerjaan sampingan

X5 : Tanggungan keluarga

\section{HASIL DAN PEMBAHASAN}

Sejarah Desa Tlagah tidak terlepas dari sejarah Masyarakat Samin di Kabupaten Pamekasan. Desa ini awalnya bernama desa Tlagah sampai sekarang dan tiap 5 tahun sekali diadakan PILKADES. Kepala Desa Tlagah adalah Kepala Desa yang dermawan dan bijaksana terhadap Masyarakatnya, karena sangat terpengaruh oleh gaya kehidupan masyarakat samin.

Adanya semangat perubahan baik pola hidup yang semakin modern maka desa ini selalu mengikuti perkembangan jaman . Nama Tlagah didasarkan pada banyaknya sumber mata air yang ada di desa ini. Adapun kepala desa yang pernah menjabat hingga sekarang adalah sebagai berikut: Ayu ( tahun 1940 s/d 1965 ), Masgending ( tahun 1965 s/d 1975 ), Asmo'i ( tahun 1976 s/d 1986 ) Abd. Azis ( tahun 1987 s/d 2006 ), dan Sutrisno ( tahun $2007 \mathrm{~s} / \mathrm{d}$ sekarang ).

Secara geografi Desa Tlagah terletak di Kecamatan Pegantenan Kabupaten Pamekasan dengan dataran tinggi yang berjarak $+5 \mathrm{Km}$ arah timur dari pusat kecamatan yang dapat ditempuh dengan waktu sekitar 8 menit. Sedangkan jarak tempuh ke ibu kota kabupaten adalah 15 $\mathrm{km}$, yang dapat ditempuh dengan waktu sekitar 25 menit.

Cukup strategis dengan luas wilayah $116.003 \mathrm{Ha}$. Yang terbagi menjadi 5 dusun, yakni : Dusun Tlagah, Dusun Bhaban, Dusun Blurah, Dusun Tonggak Jati dan Bhata - Bata dengan batas batas - batas wilayah sebagai berikut :

$\sim$ Utara : berbatasan dengan desa Lebbek Kecamatan Pakong

$\sim$ Barat : berbatasan dengan Desa Bulangan timur dan Bulangan Haji

$\sim$ Selatan : berbatasan denan desa Pamoroh kecamatan Kadur

$\sim$ Timur : berbatasan dengan desa Bicorong kecamatan Pakong 


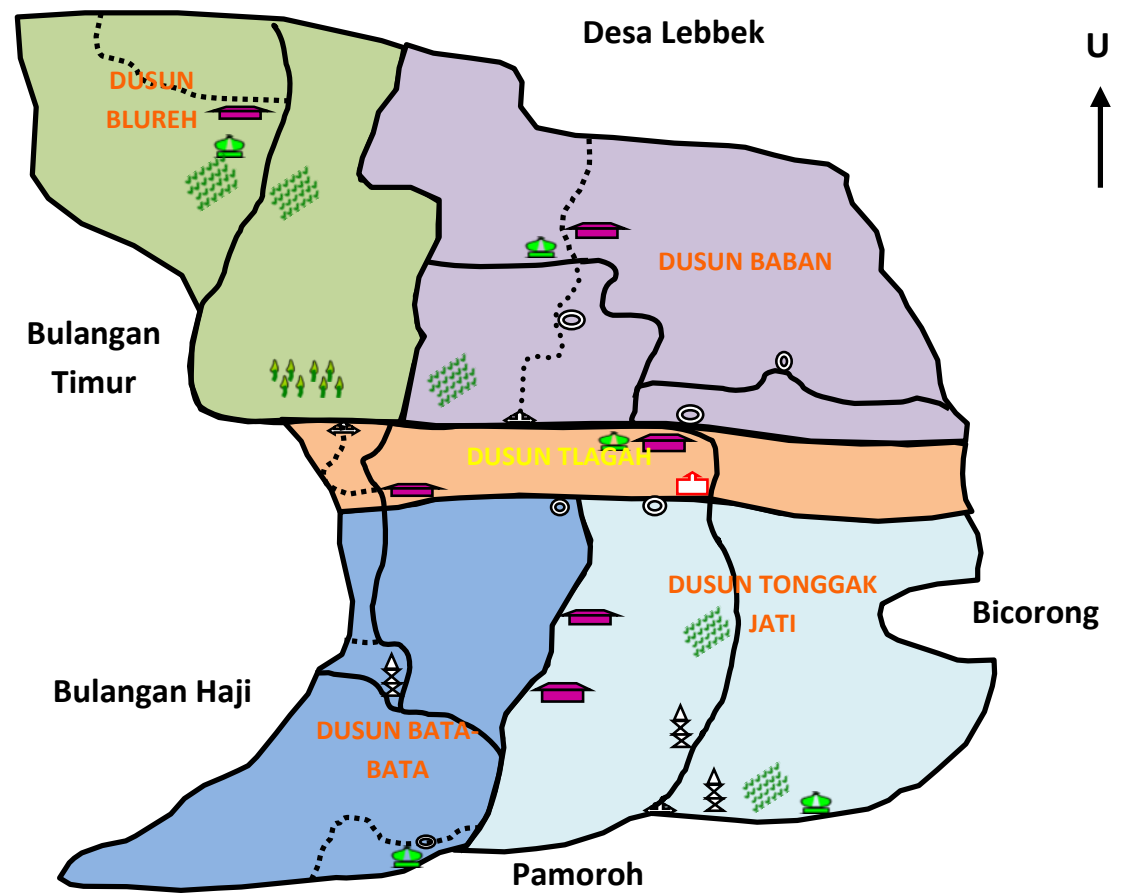

Biaya secara umum merupakan nominal uang yang dikeluarkan oleh pelaku ekonomi untuk mendapatkan barang atau jasa yang diperlukan. Bagi produsen biaya diartikan sebagai nominal uang yang dikeluarkan untuk membeli barang dan jasa yang digunakan sebagai imput dalam proses produksi, selanjutnya imput tersebut digunakan untuk memproduksi output atau komoditi. sedangkan biaya yang dikeluarkan oleh kunsumen digunakan untuk memenuhi kebutuhan konsumsi baik berupa barang maupun jasa akhir yang mampu memberikan mamfaat bagi konsumen. Biaya juga dibedakan menjadi dua yaitu biaya tetap (fixed cost) dan biaya variabel (variable cost).

\section{Biaya tetap (fixed cost)}

\section{a. Tembakau}

Biaya tetap adalah biaya yang jumlah totalnya tetap konstan, tidak dipengaruhi oleh perubahan volume kegiatan atau aktivitas sampai dengan tingkatan tertentu. Biaya tetap per unit berbanding terbalik secara proposional dengan perubahan volume kegiatan atau kapasitas. Semakin tinggi tingkat kegiatan, maka semakin rendah biaya tetap per unit. Semakin rendah tingkat kegiatan, maka semakin tinggi biaya tetap per unit. Contoh: biaya telepon, Biaya Pemeliharaan Bangunan, biaya penyusutan, adalah contoh dari faktor produksi yang dianggap tidak mengalami perubahan dalam jangka pendek. Biaya dalam penelitian ini dapat dilihat pada tabel berikut dibawah ini :

Tabel 4. Rata-rata biaya tetap usahatani tembakau dengan luas lahan rata-rata $1.700 \mathrm{~m}$.

\begin{tabular}{lll}
\hline No & Peralatan & Penyusutan $(\mathrm{Rp})$ \\
\hline 1 & Cangkul & 10.000 \\
2 & Garu & 2.000 \\
3 & Sabit & 3.000 \\
4 & Sanyo & 50.000 \\
\hline & Total & 65.000 \\
\hline
\end{tabular}

Usahatani tembakau di Desa Tlagah Pegantenan Pamekasan dalam satu kali musim biaya tetap yang dikeluarkan dalam usahatani tembakau adalah sebesar Rp. 65.000 
b. Cabai

Tabel 5. Rata-rata biaya tetap usahatani cabai dengan luas lahan rata-rata $1.700 \mathrm{~m}$.

\begin{tabular}{lll}
\hline No & Peralatan & $\begin{array}{l}\text { Penyusutan } \\
(\mathrm{Rp})\end{array}$ \\
\hline 1 & Cangkul & 10.000 \\
2 & Garu & 3.000 \\
3 & Sabit & 2.000 \\
4 & Sanyo & 50.000 \\
\hline & Total & 65.000 \\
\hline
\end{tabular}

Usahatani tembakau di Desa Tlagah Pegantenan Pamekasan dalam satu kali musim biaya tetap yang dikeluarkan dalam usahatani cabai adalah sebesar Rp. 65.000

\section{Biaya variabel (variable cost)}

a. Tembakau

Biaya variabel (Variable cost) adalah biaya yang berkaitan secara langsung dengan jumlah tanaman yang diusahakan dan input variabel yang dipakai. Biaya variabel dalam penelitian dapat dilihat pada tabel berikut ini:

Tabel 6. Rata-rata biaya variabel usahatani tembakau dengan luas lahan $1.700 \mathrm{~m}$.

\begin{tabular}{lll}
\hline No & $\begin{array}{l}\text { Komponen } \\
\text { Biaya }\end{array}$ & $\begin{array}{l}\text { Total Biaya } \\
(\mathrm{Rp})\end{array}$ \\
\hline 1 & Bibit & 140.000 \\
\hline 2 & Pupuk : & \\
& Urea & 85.000 \\
& Npk & 36.000 \\
& ZA & 85.000 \\
\hline 3 & Pestisida : & 12.000 \\
\hline 4 & Tenaga kerja : & 175.000 \\
\hline & Total & 533.000
\end{tabular}

Sumber : Data Primer diolah, 2018

Tabel 6 dapat dilihat biaya variabel biaya yang dikeluarkan dalam usahatani tembakau adalah: biaya bibit sebesar Rp. 140.000, biaya pupuk sebesar Rp. 206.000, biaya pestisida 12.000 , dan biaya tenaga kerja sebesar Rp. 175.000 jadi total biaya yang dikeluarkan adalah sebesar $\mathrm{Rp}$. 533.000

b. Cabai

Tabel 7. Rata-rata biaya variabel usahatani cabai dengan luas lahan $1.700 \mathrm{~m}$.

\begin{tabular}{lll} 
No & Komponen Biaya & $\begin{array}{l}\text { Total Biaya } \\
(\mathrm{Rp})\end{array}$ \\
\hline 1 & Bibit & 500.000 \\
\hline 2 & Pupuk : & \\
& ZA & 1.600 .000 \\
& Ampas & 200.000 \\
\hline 3 & Pestisida : & 1.400 .000 \\
\hline 4 & Tenaga kerja : & 1.600 .000 \\
\hline & Total & 5.300 .000
\end{tabular}

Sumber : Data Primer diolah, 2018

Biaya yang dikeluarkan dalam usahatani cabai biaya terbesar adalah biaya pupuk sebesar Rp. 1.800.000, kemudian biaya tenaga kerja sebesar Rp. 1.600.000, kemudian biaya pestisida sebesar Rp. 1.400.000, dan biaya bibit sebesar Rp. 500.000 jadi total biaya yang dikeluarkan adalah sebesar Rp. 5.300.000.

\section{Analisis Total Biaya (Total cost) \\ a. Tembakau}

Biaya total adalah penjumlahan dari total biaya tetap dengan total biaya variabel. Gambaran mengenai biaya total usahatani tembakau dapat dilihat pada tabel berikut ini :

Tabel 8. Rata-rata biaya usahatani tembakau dengan luas lahan $1.700 \mathrm{~m}$.

\begin{tabular}{lll}
\hline No & Uraian & Jumlah $(\mathrm{Rp})$ \\
\hline 1 & Biaya tetap & 65.000 \\
2 & Biaya variable & 533.000 \\
\hline & Total biaya & 598.000 \\
\hline
\end{tabular}

Sumber : Data Primer diolah, 2018 


\section{b. Cabai}

Tabel 9. Rata-rata biaya usahatani cabai dengan luas lahan $1.739 \mathrm{~m}$.

\begin{tabular}{lll}
\hline No & Uraian & Jumlah $(\mathrm{Rp})$ \\
\hline 1 & Biaya tetap & 65.000 \\
2 & Biaya variable & 5.300 .000 \\
\hline & Total biaya & 5.365 .000 \\
\hline \multicolumn{3}{c}{ Sumber : Data Primer diolah, 2018 }
\end{tabular}

\section{Analisis Biaya Usahatani}

a. Tembakau

Tabel 10. Rata-rata biaya usahatani tembakau dengan luas lahan $1.739 \mathrm{~m}$.

\begin{tabular}{lll}
\hline No & Uraian & Tembakau $(\mathrm{Rp})$ \\
\hline 1 & FC & 65.000 \\
2 & VC & 533.000 \\
3 & TC & 598.000 \\
\hline \multicolumn{3}{r}{ Sumber : Data Primer diolah, 2018}
\end{tabular}

TC ( Total Cost) adalah untuk mengetahui total biaya yang dikeluarkan selama satu musim usahatani tembakau, yaitu biaya tetap Rp. 65.000 + biaya variabel Rp. 533.000 maka total biaya yang dikeluarkan dalam satu musim usahatani tembakau sebesar Rp. 598.000.

\section{b. Cabai}

Tabel 11. Rata-rata biaya usahatani cabai dengan luas lahan $1.700 \mathrm{~m}$.

\begin{tabular}{lll}
\hline No & Uraian & Cabai $(\mathrm{Rp})$ \\
\hline 1 & FC & 65.000 \\
2 & VC & 5.300 .000 \\
3 & TC & 5.365 .000 \\
\hline \multicolumn{3}{c}{ Sumber : Data Primer diolah, 2018 }
\end{tabular}

TC ( Total Cost) adalah untuk mengetahui total biaya yang dikeluarkan selama satu musim usahatani cabai, yaitu biaya tetap Rp. 65.000 + biaya vareabel Rp. 5.300.000 maka total biaya yang dikeluarkan dalam satu musim usahatani cabai Rp. 5.365.000.

\section{Analisis Penerimaan Usahatani}

a. Tembakau

Penerimaan usahatani adalah nilai produksi yang di peroleh dalam jangka waktu tertentu dan merupakan hasil kali dari jumlah pruduksi dengan harga satuan dari hasil pruduksi tersebut. Harga jual tanaman tembakau rata-rata per $\mathrm{Kg}$ sebesar Rp 35.000. Dengan produksi yang dihasilkan dalam satu kali panen rata-rata $100 \mathrm{Kg}$ dengan luas lahan $1.700 \mathrm{~m}$. Mengenai penerimaan usahatani tembakau di Desa Tlagah dapat dilihat berikut ini :

Tabel 12. Rata-rata biaya usahatani tembakau dengan luas lahan $1.700 \mathrm{~m}$.

\begin{tabular}{|c|c|c|}
\hline No & Uraian & Tembakau (Rp) \\
\hline 1 & $\mathrm{Y}$ & 100 \\
\hline 2 & PY & 35.000 \\
\hline 3 & TR & 3.500 .000 \\
\hline
\end{tabular}

TR (Total Reveneu) adalah hasil penerimaan usahatani tembakau sama dengan hasil panen yang diperoleh di kalikan dengan harga jual per Kg. Dalam hasil panen yang di peroleh rata-rata sebanyak $100 \mathrm{Kg}$ dengan harga rata-rata Rp. 35.000 Maka penerimaan yang di peroleh rata-rata sebesar Rp 3.500.000.

\section{b. Cabai}

Penerimaan usahatani adalah nilai produksi yang di peroleh dalam jangka waktu tertentu dan merupakan hasil kali dari jumlah pruduksi dengan harga satuan dari hasil pruduksi tersebut. Harga jual tanaman cabai rata-rata per $\mathrm{Kg}$ sebesar Rp 12.000. Dengan produksi yang dihasilkan dalam satu kali panen rata-rata $1600 \mathrm{Kg}$ dengan luas lahan $1.700 \mathrm{~m}$. Mengenai penerimaan usahatani cabai dapat dilihat berikut ini: 
Tabel 13. Rata-rata biaya usahatani cabai dengan luas lahan $1.700 \mathrm{~m}$.

\begin{tabular}{lll}
\hline No & Uraian & Cabai $(\mathrm{Rp})$ \\
\hline 1 & Y & 1.600 \\
2 & PY & 12.000 \\
3 & TR & 19.200 .000 \\
\hline \multicolumn{3}{l}{ Sumber : Data Primer diolah, 2018 }
\end{tabular}

TR (Total Reveneu) adalah hasil penerimaan usahatani cabai sama dengan hasil panen yang diperoleh dikalikan dengan harga jual per $\mathrm{Kg}$. Dalam hasil panen yang di peroleh rata-rata sebanyak $1.600 \mathrm{Kg}$ dengan harga rata $\mathrm{Rp} 12.000$ Maka penerimaan yang di peroleh rata-rata sebesar Rp 19.200.000.

\section{Analisis Pendapatan Usahatani}

a. Tembakau

Pendapatan merupakan hasil pengurangan dari total penerimaan usahatani dengan total biaya yang dikeluarkan. Besarannya pendapatan yang diterima merupakan balas jasa untuk tenaga kerja dan modal yang di gunakan dalam usahatani. Pendapatan usahatani tembakau di Desa Tlagah yang di lakukan penelitian pada bulan juli hingga Agustus 2018. Setelah diketahui pendapatan usahatani tembakau, kemudian peneliti melakukan penghitungan $\mathrm{R} / \mathrm{C}$ rasio untuk mengetahui keuntungan usahatani tembakau serta kelanjutan usahatani tembakau. Pendapatan usahatani tembakau merupakan hasil dari penerimaan dikurangi biaya total yang dikeluarkan.

Tabel 14. Rata-rata biaya usahatani tembakau dengan luas lahan $1.700 \mathrm{~m}$.

\begin{tabular}{lll}
\hline No & Uraian & $\begin{array}{l}\text { Tembakau } \\
(\mathrm{Rp})\end{array}$ \\
\hline 1 & TR & 3.500 .000 \\
2 & TC & 598.000 \\
3 & $\pi$ & 2.902 .000 \\
\hline \multicolumn{3}{c}{ Sumber : Data Primer diolah, 2018 }
\end{tabular}

$\boldsymbol{\pi}$ (pendapatan) yaitu diperoleh dari hasil pengurangan antara penerimaan dan total biaya, yaitu penerimaanya sebesar Rp. 3.500 .000 - total biaya Rp. $598.000=R$ p. 2.902.000 jadi pendapatan diperoleh dari produksi tembakau adalah Rp. 2.902.000.

b. Cabai

Pendapatan usahatani cabai merupakan hasil dari penerimaan dikurangi biaya total yang keluarkan.

Tabel 15. Rata-rata biaya usahatani cabai dengan luas lahan $1.700 \mathrm{~m}$.

\begin{tabular}{lll}
\hline No & Uraian & Cabai $(\mathrm{Rp})$ \\
\hline 1 & TR & 19.200 .000 \\
2 & TC & 5.365 .000 \\
3 & $\Pi$ & 13.835 .000 \\
\hline
\end{tabular}

$\boldsymbol{\pi}$ (pendapatan) yaitu diperoleh dari hasil pengurangan antara penerimaan dan total biaya, yaitu penerimaanya sebesar Rp. 19.200.000 - total biaya Rp. $5.365 .000=$ Rp. 13.835.000 jadi pendapatan diperoleh dari produksi cabai adalah Rp. 13.835.000.

\section{R/C Rasio}

\section{a. Tembakau}

R/C Rasio (Kelayakan) adalah pembagian antara penerimaan usahatani dengan biaya yang dikeluarkan. Nilai R/C rasio sebesar 5,86 yang menunjukkan bahwa usahatani tembakau di Desa Tlagah menguntungkan. Penghitungan $\mathrm{R} / \mathrm{C}$ rasio untuk mengetahui tingkat efisiensi yang diperoleh dari perbandingan antara penerimaan dengan total biaya.

Tabel 16. Hasil analisis R/C Rasio usahatani tembakau dengan luas lahan ratarata $1.700 \mathrm{~m}$.

\begin{tabular}{lll}
\hline No & Uraian & Jumlah $(\mathrm{Rp})$ \\
\hline 1 & Penerimaan & Rp. 3.500 .000 \\
2 & Total biaya & Rp. 598.000 \\
\hline & R/C Rasio & 5,86 \\
\hline
\end{tabular}

Sumber : Data Primer diolah, 2018 
Berdasarkan teori yang di kemukan oleh Soekartawi bahwa usaha tersebut bisa dikatakan menguntungkan jika nilai $\mathrm{R} / \mathrm{C}$ rasio lebih besar dari satu $(\mathrm{R} / \mathrm{C}>1)$. Hal tersebut menunjukkan bahwa setiap nilai rupiah yang di keluarkan dalam produksi akan memberikan mamfaat sejumlah nilai penerimaan yang diperoleh. dari penghitungan $\mathrm{R} / \mathrm{C}$ rasio sebesar 5,86 menunjukkan bahwa $\mathrm{R} / \mathrm{C}>1$. Nilai $\mathrm{R} / \mathrm{C}$ Rasio ini menggambarkan bahwa setiap rupiah pengeluaran dalam usahatani tembakau tersebut akan menghasilkan penerimaan sebesar Rp. 5,86 maka usahatani tembakau menguntungkan.

\section{b. Cabai}

R/C Rasio (Kelayakan) adalah pembagian antara penerimaan usahatani dengan biaya yang dikeluarkan. Nilai R/C rasio sebesar 3,58 yang menunjukkan bahwa usahatani cabai putih di Desa Tlagah menguntungkan. Penghitungan $\mathrm{R} / \mathrm{C}$ Rasio untuk mengetahui tingkat efisiensi yang diperoleh dari perbandingan antara penerimaan dengan total biaya pada tabel berikut.

Tabel 17. Hasil analisis R/C Rasio usahatani cabai dengan luas lahan rata-rata $1.700 \mathrm{~m}$.

\begin{tabular}{lll}
\hline No & Uraian & Jumlah (Rp) \\
\hline 1 & Penerimaan & Rp. 19.200 .000 \\
2 & Total biaya & Rp. 5.365.000 \\
\hline & R/C Rasio & 3,58 \\
\hline \multicolumn{3}{c}{ Sumber : Data Primer diolah, 2018 }
\end{tabular}

Berdasarkan teori yang di kemukan oleh Soekartawi bahwa usaha tersebut bisa dikatakan menguntungkan jika nilai $\mathrm{R} / \mathrm{C}$ rasio lebih besar dari satu $(\mathrm{R} / \mathrm{C}>1)$. Hal tersebut menunjukkan bahwa setiap nilai rupiah yang di keluarkan dalam produksi akan memberikan mamfaat sejumlah nilai penerimaan yang diperoleh. Dari penghitungan $\mathrm{R} / \mathrm{C}$ rasio sebesar 3,58 menunjukkan bahwa $\mathrm{R} / \mathrm{C}>1$. Nilai $\mathrm{R} / \mathrm{C}$ Rasio ini menggambarkan bahwa setiap rupiah pengeluaran dalam usahatani cabai tersebut akan menghasilkan penerimaan sebesar Rp 3,58 maka usahatani menguntungkan.

\section{B/C Rasio}

a. Tembakau

B/C Rasio adalah perbandingan antara pendapatan dengan total biaya yang di keluarkan. Berdasarkan pendapatan dan total biaya yang di keluarkan nilai $\mathrm{B} / \mathrm{C}$ rasio sebesar 4,86. Dengan tersebut menunjukkan bahwa usahatani tembakau di desa Tlagah menguntungkan untuk di lanjutkan. Penghitungan analisis $\mathrm{B} / \mathrm{C}$ rasio sebagai berikut:

Tabel 18. Hasil B/C Rasio usahatani tembakau dengan luas lahan rata-rata 1.700 m.

\begin{tabular}{|c|c|c|}
\hline No & Uraian & Jumlah (Rp) \\
\hline 1 & Pendapatan & Rp. 2.902 .000 \\
\hline 2 & Total biaya & Rp. 598.000 \\
\hline & B/C Rasio & 4,86 \\
\hline
\end{tabular}

Untuk penghitungan $\mathrm{B} / \mathrm{C}$ rasio sesuai dengan teorinya bahwa suatu usaha di katakan layak dan meberikan manfaat nilai $\mathrm{B} / \mathrm{C}$ Rasio lebih besar dari nol $(\mathrm{B} / \mathrm{C}>0)$. semakin besar nilai $\mathrm{B} / \mathrm{C}$ rasio maka semakin besar nilai mamfaat yang akan di peroleh usahatani tersebut. Dari hasil penghitungan $\mathrm{B} / \mathrm{C}$ Rasio sebesar 4,86 menunjukkan bahwa $\mathrm{B} / \mathrm{C}>0$.

\section{b. Cabai}

$\mathrm{B} / \mathrm{C}$ Rasio adalah perbandingan antara pendapatan dengan total biaya yang di keluarkan. Berdasarkan pendapatan dan total biaya yang di keluarkan nilai $\mathrm{B} / \mathrm{C}$ rasio sebesar 2,58. Dengan tersebut menunjukkan bahwa usahatani cabai di desa Tlagah menguntungkan untuk di lanjutkan. Penghitungan analisis $\mathrm{B} / \mathrm{C}$ rasio sebagai berikut: 
Tabel 19. hasil B/C Rasio usahatani cabai dengan luas lahan rata-rata $1.700 \mathrm{~m}$.

\begin{tabular}{lll}
\hline No & Uraian & Jumlah $(\mathrm{Rp})$ \\
\hline 1 & Pendapatan & Rp. 13.835 .000 \\
2 & Total biaya & Rp. 5.365 .000 \\
\hline & B/C Rasio & 2,58 \\
\hline
\end{tabular}

Sumber : Data Primer diolah, 2018

Untuk penghitungan $\mathrm{B} / \mathrm{C}$ rasio sesuai dengan teorinya bahwa suatu usaha di katakan layak dan memberikan mamfaat penilai B/C Rasio lebih besar dari nol (B/C $>0$ ). semakin besar nilai $\mathrm{B} / \mathrm{C}$ rasio maka semakin besar nilai mamfaat yang akan di peroleh usahatani tersebut. Dari hasil penghitungan $\mathrm{B} / \mathrm{C}$ Rasio sebesar 2,58 menunjukkan bahwa $\mathrm{B} / \mathrm{C}>0$.

\section{Analisis faktor-faktor yang mempengaruhi alih komoditas dari tembakau ke sayur-mayur}

\section{Karakteristik Responden}

Responden yang dijadikan sampel pada penelitian ini adalah para petani yang melakukan alih fungsi lahan tembakau ke cabai dan petani yang tetap menanam tembakau. Responden pada penelitian ini sebanyak 57 orang. Identitas responden berdasarkan umur, tingkat pendidikan, pekerjaan sampingan, jumlah tanggungan keluarga, dan penghasilan petani perbulan.

\section{a. Umur}

Umur seorang petani berpengaruh terhadap perilaku dan kemampuan fisiknya untuk bekerja. Umumnya petani yang masih muda dan sehat relatif lebih mudah menerima teknologi dan berani menanggung resiko serta memiliki kemampuan fisik yang lebih kuat dalam bekerja dibandingkan dengan petani yang sudah berusia lanjut.

Tabel 20. Distribusi Responden Berdasarkan Umur

\begin{tabular}{llll}
\hline No & Umur & Jumlah (Orang) & Presentase $\%$ \\
\hline 1 & $<20$ Tahun & - & - \\
2 & 20 Tahun - 30 Tahun & - & - \\
3 & 30 Tahun - 40 Tahun & 22 & $39 \%$ \\
4 & 40 Tahun - 50 Tahun & 16 & $28 \%$ \\
5 & 50 Tahun - 60 Tahun & 19 & $33 \%$ \\
\hline Jumlah & 57 & $100 \%$ \\
\hline
\end{tabular}

Sumber : Data Primer Diolah, 2018

Berdasarkan tabel diatas dapat diketahui bahwa semua responden berada pada usia produktif. Jumlah terbanyak pada kisaran umur 30 - 40 tahun yaitu sebanyak 22 0rang dengan persentase $39 \%$ , dan responden pada umur 40 - 50 tahun sebanyak 16 orang dengan persentase $28 \%$ , sedangkan responden pada umur $50-60$ tahun sebanyak 19 orang dengan persentase $33 \%$. Dari tabel diatas dapat disimpulkan semua responden pada penelitian ini masih berada dalam usia yang cukup produktif dalam berusahatani dengan persentase $100 \%$.

\section{b. Tingkat Pendidikan}

Pendidikan merupakan salah satu usaha untuk meningkatkan kualitas sumber daya manusia. Semakin tinggi tingkat pendidikan petani, diharapkan pola pikir dan perilaku petani semakin rasional. Sehingga petani lebih mudah dan cepat menerima teknologi baru untuk peningkatan produksi usahanya. Tingkat pendidikan responden pada penelitian ini dapat dilihat pada Tabel 21 : 
Tabel 21. Distribusi Responden Berdasarkan Tingkat Pendidikan

\begin{tabular}{llll}
\hline No & Tingkat Pendidikan & Jumlah (Orang) & Presentase $\%$ \\
\hline 1 & Tidak lulus & 51 & $88 \%$ \\
2 & SD & 1 & $2 \%$ \\
3 & SMP & 1 & $2 \%$ \\
4 & SMA & 2 & $4 \%$ \\
5 & Sarjana & 2 & $4 \%$ \\
\hline Jumlah & & 57 & $100 \%$ \\
\hline
\end{tabular}

Sumber : Data Primer Diolah, 2018

Berdasarkan tabel diatas dapat diketahui bahwa tingkat pendidikan responden pada penelitian ini terbanyak adalah tidak berpendidikan yaitu sebanyak 51 orang dengan persentase $88 \%$, dan yang berpendidikan SD dan SMP masingmasing sebanyak 1 orang dengan persentase $2 \%$ sedangkan yang berpendidikan SMA dan Sarjana masingmasing sebanyak 2 orang dengan persentase $4 \%$.
Dari tabel diatas dapat disimpulkan bahwa mayoritas pendidikan petani masih kurang, sehingga penerapan teknologi dan penyaluran informasi menjadi lamban.

\section{c. Pekerjaan Sampingan}

Pekerjaan sampingan yang dimaksud ialah responden yang melakukan pekerjaan lain guna untuk mencukupi kebutuhan sehari - hari. Adapun jenis pekerjaan responden diluar pertanian pada penelitian ini dapat dilihat pada Tabel 22 :

Tabel 22. Distribusi Responden Berdasarkan Pekerjaan Sampingan

\begin{tabular}{llll}
\hline No & Pekerjaan Sampingan & Jumlah (Orang) & Persentase $\%$ \\
\hline 1 & Tidak ada & 7 & $12 \%$ \\
2 & Pegawai Swasta & 6 & $10 \%$ \\
3 & PNS & - & - \\
4 & Wiraswasta/Berdagang & 10 & $18 \%$ \\
5 & Lain - lain & 34 & $60 \%$ \\
\hline Jumlah & 57 & $100 \%$ \\
\hline
\end{tabular}

Berdasarkan tabel diatas dapat diketahui bahwa pekerjaan sampingan responden pada penelitian ini ialah responden yang tidak mempunyai pekerjaan sebanyak 7 orang dengan persentase $12 \%$, responden yang menjadi pegawai swasta sebanyak 6 Orang dengan persentase $10 \%$ responden yang menjadi pedagang sebanyak 10 orang dengan persentase $18 \%$, dan responden yang kerja serabutan yaitu sebanyak 34 orang dengan persentase $60 \%$.

Dari tabel diatas dapat disimpulkan bahwa mayoritas keadaan petani tidak mempunyai pekerjaan tetap sehingga mendorong petani mencari keuntungan yang maksimal dari lahan pertanian yang mereka punya. 


\section{d. Jumlah Tanggungan Keluarga}

Aspek yang cukup berpengaruh terhadap peningkatan kesejahteraan petani adalah besarnya tanggungan setiap kepala keluarga dalam mencukupi kebutuhan sehari-harinya. Jumlah tanggungan keluarga petani menandakan tingkat kemampuan dan merupakan tanggung jawab terhadap pemenuhan kebutuhan dan kesejahteraan bagi seluruh anggota keluarganya. Adapun jumlah tanggungan keluarga responden pada penelitian ini dapat dilihat pada Tabel 23 :

Tabel 23. Distribusi Responden Berdasarkan Jumlah Tanggungan Keluarga

\begin{tabular}{llll}
\hline No & Tanggungan Keluarga & Jumlah (Orang) & Presentase $\%$ \\
\hline 1 & $1-5$ Orang & 31 & $54 \%$ \\
2 & $5-6$ Orang & 14 & $25 \%$ \\
3 & $6-10$ Orang & 12 & $21 \%$ \\
4 & $>10$ Orang & - & - \\
\hline Jumlah & 57 & $100 \%$ \\
\hline
\end{tabular}

Berdasarkan tabel diatas diketahui jumlah tanggungan keluarga 1-5 orang berjumlah 31 orang dengan persentase 54 $\%$, reponden yang mempunyai tanggungan keluarga 5-6 orang sebanayk 14 responden dengan persentase $25 \%$ sedangkan yang mempunyai tanggungan keluarga 6-10 orang sebanyak 12 orang dengan persentase $21 \%$. Maka dapat disimpulkan semakin besar jumlah tanggungan dalam sebuah rumah tangga, maka akan mempengaruhi besarnya pendapatan yang diterima oleh petani.

\section{e. Penghasilan Rumah Tangga Perbulan}

Dalam kehidupan rumah tangga baik ditingkat keluarga maupun pemerintahan pasti membutuhkan biaya untuk memenuhi kebutuhan hidupnya sehari-hari. Biaya tersebut diperoleh dari penghasilan seluruh anggota keluarga tersebut. Penghasilan dan pengeluaran dalam suatu rumah tangga pasti berbeda-beda.

Bagi rumah tangga pedesaan yang hanya menguasai faktor produksi tenaga kerja, pendapatan mereka ditentukan oleh besarnya kesempatan kerja yang dapat dimanfaatkan dan tingkat upah yang diterima.

Tabel 24. Distribusi Responden Berdasarkan Penghasilan Rumah Tangga Perbulan

\begin{tabular}{llll}
\hline No & Total Pendapatan Rumah Tangga (bulan) & Jumlah (Responden) & Presentase \% \\
\hline 1 & $<$ Rp 500.000 & - & - \\
2 & Rp 500.000 - 1 juta & 15 & $26 \%$ \\
3 & Rp 1 juta - Rp 4 juta & 40 & $70 \%$ \\
4 & Rp 4 juta - Rp 5 juta & 2 & $4 \%$ \\
5 & $>5$ juta & - & - \\
\hline Jumlah & 57 & $100 \%$ \\
\hline
\end{tabular}

Berdasarkan tabel diatas dapat diketahui bahwa responden yang mempunyai penghasilan diantara $\mathrm{Rp} 1$ - 4 juta sebanyak 40 orang dengan persentase
$70 \%$ dan responden yang mempunyai penghasilan Rp 4 - 5 juta perbulan sebanyak 2 orang dengan persentase $4 \%$ sedangkan responden yang mempunyai 
penghasilan diantara $\mathrm{Rp} 500.000$ - Rp 1 juta sebanyak 15 orang dengan persentase $26 \%$. Maka dapat disimpulkan penghasila rata-rata rumah tangga petani masih kurang mencukupi kebutuhan sehari-hari petani.

\section{f. Keikut sertaan dalam kelompok tani}

Keikut sertaan dalam kelompok tani sangatlah berpengaruh pada setiap petani, karna petani dapat belajar banyak hal yang berkaitan dengan pertanian. Petani yang ikut kelompok tani akan lebih bervariasi dan berkembang dalam usahataninya. Bahkan mereka akan mendapatkan teoriteori tentang cara bercocok tanam, tentang tanaman apa yang paling pas untuk ditanam saat itu, tentang benih yang baik, cara pemberantasan hama, dan lain sebagainya. Petani akan lebih mudah dalam bertani dan akan mendapatkan hasil yang lebih daripada petani yang tidak ikut kelompok tani. Berikut adalah daftar responden yang ikut dalam kelompok tani.

Tabel 25. Keikut sertaan dalam kelompok tani

\begin{tabular}{llll}
\hline No & Keikut sertaan kelompok tani & Jumlah (Orang) & Presentase $\%$ \\
\hline 1 & Ikut & 44 & $88 \%$ \\
2 & Tidak ikut & 6 & $12 \%$ \\
\hline Jumlah & 50 & $100 \%$ \\
\hline
\end{tabular}

Sumber : Data Primer Diolah, 2018

Berdasarkan tabel diatas diketahui bahwa jumlah petani yang ikut kelompok tani lebih banyak daripada yang tidak ikut sebanyak 44 orang dengan persentase 88 $\%$. Sedangkan yang tidak ikut sebanyak 6 orang dengan persentase $12 \%$. Maka dapat disimpulkan bahwa keikut sertaan dalam kelompok tani berpengaruh terhadap petani.

\section{a. Hasil Uji Asumsi Klasik}

Pada penelitian ini data yang dianalisis ialah faktor-faktor yang memepengaruhi perilaku petani dalam alih fungsi lahan tembakau menjadi lahan cabai di Desa Tlagah Barat Kecamatan Pagantenan diantaranya:
a. Faktor Usia
b. Faktor Tingkat Pendidikan
c. Faktor keikut sertaan kelompok tani
d. Faktor pekerjaan sampingan
e. Faktor tanggungan keluarga

Sedangkan data yang diolah pada penelitian ini dapat dilihat pada lampiran 3 .

\section{b. Hasil Uji Normalitas}

Tabel 26. Hasil Uji Normalitas

One-Sample Kolmogorov-Smirnov Test

\begin{tabular}{|ll|l|}
\hline \multicolumn{1}{|c|}{} & RES \\
\hline $\mathrm{N}$ & Mean & 57 \\
Normal & .1204 \\
Parameters & & \\
& Std. Deviation & .09348 \\
Most Extreme & Absolute & .145 \\
Differences & Positive & .145 \\
& Negative & -.110 \\
Kolmogorov-Smirnov Z & 1.097 \\
Asymp. Sig. (2-tailed) & .180 \\
\hline
\end{tabular}

a. Test distribution is Normal.

b. Calculated from data.

Uji normalitas bertujuan untuk menguji apakah data berdistribusi normal atau tidak salah satu pengujian normalitas pada model regresi dapat menggunakan uji One-Sample Kolmogorov. Pada penelitian ini didapat hasil asymptotic significance sebesar 0.180 yang lebih besar dari 0.05 . berdasarkan hasil tersebut maka dapat 
disimpulkan bahwa data berdistribusi normal.

\section{c. Hasil Uji Multikolinieritas}

Uji moltikolinieritas bertujuan untuk mengetahui apakah terjadi hubungan antar variabel independent dengan variable independent lainnya. Model regresi yang baik seharusnya tidak terjadi hubungan antar variabel independennya, apabila terjadi hubungan maka terjadi masalah multikolinieritas. Gejala multikolinieritas dapat dilihat dengan nilai VIF (varian infletion faktor). Jika nilai $\mathrm{VIF}<10$ maka tidak ada gejala multikolinieritas. Hasil pengujian terhadap multikolineritas dapat dilihat pada tabel 19.

Tabel 27. Hasil Uji Moltikolinieritas

Coefficients $^{\mathrm{a}}$

\begin{tabular}{|l|l|l|l|l|l|l|}
\hline \multirow{2}{*}{ Model } & \multicolumn{2}{|l|}{$\begin{array}{l}\text { Unstandardized } \\
\text { Coefficients }\end{array}$} & \multirow{2}{*}{$\mathrm{T}$} & \multicolumn{2}{|c|}{ Sig. } & \multicolumn{2}{|l|}{ Collinearity Statistics } \\
\cline { 2 - 3 } & $\mathrm{B}$ & Std. Error & & & Tolerance & VIF \\
\hline 1 (Constant) & 1.028 & .167 & 6.159 & .000 & & \\
VAR00002 & -.100 & .045 & -2.237 & .030 & .924 & 1.082 \\
VAR00003 & -.008 & .001 & -7.811 & .000 & .624 & 1.604 \\
VAR00004 & -.005 & .005 & -1.011 & .317 & .909 & 1.100 \\
VAR00005 & -.068 & .026 & -2.628 & .011 & .772 & 1.295 \\
VAR00006 & $5.017 \mathrm{E}-5$ & .000 & 21.320 & .000 & .658 & 1.519 \\
\hline
\end{tabular}

a. Dependent Variable: VAR00001

Berdasarkan uji multikolinieritas nilai VIF pada semua variabel independen kurang dari 10. Hal ini menunjukkan bahwa variablel yang dimasukkan dalam model yang meliputi faktor ekonomi, kondisi lahan, pengalaman berusaha tani, tingkat pendidikan dan pendapatan tidak terdapat korelasi antar variabel independennya.

\section{d. Hasil Uji Autokorelasi}

Uji autokorelasi bertujuan untuk mengetahui apakah dalam suatu model regresi linier ada korelasi antar kesalahan pengganggu dengan kesalahan sebelumnya. Uji autokorelasi menggunakan uji Durbin-Watson. Jika $\mathrm{dl}<\mathrm{dw}<\mathrm{du}$ berarti tidak ada autokorelasi positif

Tabel 28. Hasil Uji Autokorelasi

Model Summary ${ }^{\mathrm{b}}$

\begin{tabular}{|l|l|l|l|l|l|}
\hline Model & $\mathrm{R}$ & R Square & $\begin{array}{l}\text { Adjusted R } \\
\text { Square }\end{array}$ & $\begin{array}{l}\text { Std. Error of the } \\
\text { Estimate }\end{array}$ & Durbin-Watson \\
\hline 1 & $.953^{\mathrm{a}}$ & .908 & .899 & .16058 & 1.183 \\
\hline
\end{tabular}

a. Predictors: (Constant), VAR00006, VAR00002, VAR00004, VAR00005, VAR00003

b. Dependent Variable: VAR00001 
Nilai du pada penelitian ini 1,7675 dan dl sebesar 1,3885 nilai dw pada uji model regresi sebesar 1,183. Nilai dw lebih kecil dari dl dan lebih kecil dari du yaitu $1,3885>1,183<1,7675$ dalam hal ini menunjukkan bahwa terdapat gejala autokorelasi, tetapi dalam penelitian ini jenis data yang digunakan menurut waktunya menggunakan data crossection sehingga hasil dari autokorelasi tidak berpengaruh terhadap model regresi yang digunakan.

\section{e. Model Regresi Binary Logistik (LOGIT)}

Pada model regresi binary logistik (LOGIT) data yang diolah pada penelitian ini dapat dilihat pada lampiran 3.

Tabel 29. Model Regresi Binary Logistik (LOGIT)

Classification Table ${ }^{\mathrm{a}, \mathrm{b}}$

\begin{tabular}{|lll|l|l|l|}
\hline \multirow{2}{*}{ Observed } & \multicolumn{3}{|l|}{ Predicted } \\
\cline { 3 - 5 } & & \multicolumn{2}{l|}{ VAR00001 } & \multirow{2}{*}{ Percentage Correct } \\
\cline { 3 - 6 } & & .00 & 1.00 & \\
\hline Step 0 & VAR00001 & .00 & 29 & 0 & 100.0 \\
& 1.00 & 28 & 0 & .0 \\
& & & & \\
\hline
\end{tabular}

a. Constant is included in the model.

b. The cut value is, 500

Berdasarkan data observasi diatas dapat dilihat bahwa terdapat 57 responden dalam mengambil keputusan untuk beralih usahatani dari tanaman tembakau ke sengon. Keputusan petani untuk beralih dari tembakau ke cabai adalah sebanyak 28 responden, sedangkan yang tetap berusahatani tembakau adalah sebanyak 29 responden. Jadi, persentase kebenaran yang didapat adalah sebesar $100 \%$ dengan tingkat kesalahan sebesar 5\%.

\section{f. Data Observasi}

Tabel 30. Data Observasi

Classification Table ${ }^{\text {a }}$

\begin{tabular}{|lll|l|l|l|}
\hline \multirow{2}{*}{ Observed } & \multicolumn{2}{|l|}{ Predicted } \\
\cline { 3 - 5 } & \multicolumn{2}{|l|}{ VAR00001 } & Percentage Correct \\
\cline { 3 - 5 } & & .00 & 1.00 & \\
\hline Step 1 & VAR00001 & .00 & 29 & 0 & 100.0 \\
& 1.00 & 0 & 28 & 100.0 \\
& & & & 100.0 \\
\hline
\end{tabular}

a. The cut value is , 500

Berdasarkan kedua tabel diatas didapatkan suatu data perediksi dalam keputusan petani untuk beralih dari usahatani tembakau ke usahatani cabai yang mana terdapat 57 responden untuk 
melakukan alih fungsi lahan tembakau ke lahan cabai atau tidak.

Keputusan petani yang tetap menanam tembakau sebanyak 29 orang. Dalam prediksi Logit, diprediksikan ke-29 orang tersebut adalah petani yang tetap berusahatani tembakau dengan persentase kebenaran sebesar $100 \%$.

Petani yang memutuskan untuk beralih dari tembakau ke cabai adalah sebanyak 28 orang. Dalam prediksi Logit, diprediksikan ke 28 orang tersebut seluruhnya memutuskan untuk beralih dari tembakau ke cabai dengan persentase kebenaran sebesar $100 \%$.
Dalam data observasi telah ditunjukkan bahwa petani yang tetap menanam tembakau sebesar 29 responden sedangkan Petani yang memutuskan untuk beralih dari tembakau ke cabai sebesar 28 responden. Setelah dilakukan analisis model tidak terjadi penyimpangan baik yang beralih dari tembakau ke cabai maupun yang tetap berusahatani tembakau.

\section{Uji Likelihood}

Penilaian mengenai baik tidaknya sebuah model dapat dilihat dari nilai log likelihood pada block 0 (beginning block) dan pada block 1 (method).

\section{Log likelihood block-0}

Iteration History ${ }^{\mathrm{a}, \mathrm{b}, \mathrm{c}}$

\begin{tabular}{|c|c|c|c|}
\hline \multirow{2}{*}{\multicolumn{2}{|c|}{ Iteration }} & \multirow{2}{*}{-2 Log likelihood } & Coefficients \\
\hline & & & Constant \\
\hline \multirow[t]{2}{*}{ Step 0} & 1 & 79.001 & -.035 \\
\hline & 2 & 79.001 & -.035 \\
\hline
\end{tabular}

a. Constant is included in the model.

b. Initial -2 Log Likelihood: 79,001

c. Estimation terminated at iteration number 2 because parameter estimates changed by less than ,001.

\section{Log likelihood block-1}

Model Summary

\begin{tabular}{|l|l|l|l|}
\hline Step & -2 Log likelihood & Cox \& Snell R Square & $\begin{array}{l}\text { Nagelkerke R } \\
\text { Square }\end{array}$ \\
\hline 1 & $39.244^{\mathrm{a}}$ & .502 & .670 \\
\hline
\end{tabular}

a. Estimation terminated at iteration number 8 because parameter estimates changed by less than ,001.

Dari hasil SPSS diatas didapatkan nilai log likelihood block-0 sebesar 79,001. Sedangkan nilai log likelihood block-1 didapatkan sebesar 39,244. Suatu model dikatakan baik jika nilai log likelihood block-0 lebih besar_dari log likelihood block-1. Dari kedua nilai hasil tersebut dapat dilihat jika nilai log likelihood block0 lebih besar_dari log likelihood block-1 yaitu $79,001>39,244$. Sehingga model persamaan yang digunakan yang meliputi variabel ekonomi, kondisi lahan, pengalaman berusahatani, tingkat pendidikan, pendapatan dan variabel dummy keputusan petani untuk beralih dari tanaman tembakau ke cabai ini dapat dikatakan model yang BAIK. 


\section{Uji Wald}

Uji wald bertujuan untuk mengetahui pengaruh variabel independen secara parsial dan melihat nilai signifikansi tiap variable independen. Hasil uji wald dalam penelitian ini dapat dilihat pada Tabel 30.

Tabel 31. Hasil Uji Wald

Variables in the Equation

\begin{tabular}{|ll|l|l|l|l|l|l|}
\hline & & B & S.E. & Wald & Df & Sig. & Exp(B) \\
\hline Step 1 $1^{\text {a }}$ & Ekonomi & -1.105 & .815 & 1.840 & 1 & .175 & .331 \\
& Kondisi Lahan & -.358 & .128 & 7.878 & 1 & .005 & .699 \\
& Pengalaman & -.083 & .104 & .640 & 1 & .424 & .920 \\
Pendidikan & .376 & .464 & .657 & 1 & .418 & 1.457 \\
pendapatan & .030 & .011 & 8.214 & 1 & .004 & 1.031 \\
Constant & 2.635 & 3.135 & .707 & 1 & .401 & 13.947 \\
\hline
\end{tabular}

a. Variable(s) entered on step 1: VAR00002, VAR00003, VAR00004, VAR00005, VAR00006.

Ket : Dikatakan signifikan/berpengaruh apabila tingkat kesalahan yang digunakan lebih besar dari data $(P$ value), artinya tolak $\mathrm{H}_{0}$ dan terima $\mathrm{H}_{\mathrm{a}}$.

\section{Faktor Ekonomi}

Pada Variabel Ekonomi $\left(\mathrm{X}_{1}\right)$ dalam Variables in the equation, nilai P-value sebesar 0.175 , sehingga dapat disimpulkan bahwa tolak $\mathrm{H}_{0}$ dan terima $\mathrm{H}_{\mathrm{a}}$, artinya parameter tersebut signifikan secara statistic pada tingkat kesalahan $\alpha=20 \%$. Serta pada Exp (B) menunjukkan nilai yang artinya bahwa peluang untuk beralih dari tanaman tembakau ke cabai yang dipengaruhi oleh variabel ekonomi 0.331 kali lebih besar peluangnya dari pada peluang untuk tetap berusahatani tembakau. Nilai koefisien faktor ekonomi mempunyai tanda negatif, artinya semakin besar pendapatan ekonomi petani maka keputusan petani untuk beralih dari tanaman tembakau ke cabai semakin kecil.

Berdasarkan fakta dilapangan petani yang melakukan alih fungsi lahan tembakau menjadi lahan cabai mayoritas termasuk dalam golongan masyarakat berekonomi menengah kebawah, dengan total penghasilan keluarga rata-rata $\mathrm{Rp}$. 1.000 .000 - Rp. 2.000 .000 perbulan.
2. Variabel Kondisi Lahan

Pada Variabel Kondisi Lahan $\left(\mathrm{X}_{2}\right)$ dalam Variables in the equation, nilai $P$ value sebesar 0.005 , sehingga dapat disimpulkan bahwa tolak $\mathrm{H}_{0}$ dan terima $\mathrm{H}_{\mathrm{a}}$, artinya parameter tersebut signifikan secara statistic pada tingkat kesalahan $\alpha=$ 1\%. Serta pada Exp (B) menunjukkan nilai yang artinya bahwa peluang untuk beralih dari tanaman tembakau ke cabai yang dipengaruhi oleh variabel kondisi lahan 0,699 kali lebih besar peluangnya daripada peluang untuk tetap berusahatani tembakau. Nilai koefisien faktor kondisi lahan mempunyai tanda negatif, artinya semakin Luas Lahan milik petani maka keputusan petani untuk beralih dari tanaman tembakau ke cabai semakin kecil.

Berdasarkan fakta dilapangan petani yang melakukan alih fungsi lahan tembakau menjadi lahan cabai termasuk petani yang mempunyai luas lahan yang kecil yaitu sekitar $50 \mathrm{~m}^{2}-200 \mathrm{~m}^{2}$, karena lahan yang dikonfersi ke cabai hanya lahan yang dulunya ditanami tembakau. 
3. Faktor Pengalaman Berusahatani

Pada Variabel Pengalaman

Berusahatani $\left(\mathrm{X}_{3}\right)$ dalam Variables in the equation, nilai $P$-value sebesar 0.424 , sehingga dapat disimpulkan bahwa terima $\mathrm{H}_{0}$ dan tolak $\mathrm{H}_{\mathrm{a}}$, artinya parameter tersebut tidak signifikan secara statistic pada tingkat kesalahan $\alpha=20 \%$. artinya pengalaman petani dalam berusahatani tidak berpengaruh nyata terhadap keputusan petani untuk beralih dari tanaman tembakau ke sengon.

Berdasarkan fakta dilapangan petani yang melakukan alih fungsi lahan tembakau menjadi lahan cabai mayoritas sebelumnya sudah berpengalaman dalam usahatani tembakau.

\section{Faktor Pendidikan}

Pada Variabel Pendidikan $\left(\mathrm{X}_{4}\right)$ dalam Variables in the equation, nilai $P$ value sebesar 0.418 , sehingga dapat disimpulkan bahwa terima $\mathrm{H}_{0}$ dan tolak $\mathrm{H}_{\mathrm{a}}$, artinya parameter tersebut tidak signifikan secara statistik pada tingkat kesalahan $\alpha=$ $20 \%$. Artinya tingkat pendidikan petani tidak berpengaruh nyata terhadap keputusan petani untuk beralih dari tanaman tembakau ke sengon.

Berdasarkan fakta dilapangan petani yang melakukan alih fungsi lahan tembakau menjadi lahan cabai mayoritas berpendidikan rendah. Sehingga petani gampang terpengaruh terhadap informasiinformasi dari luar.

\section{Faktor Pendapatan}

Pada Variabel Pendapatan $\left(\mathrm{X}_{5}\right)$ dalam Variables in the equation, nilai $P$ value sebesar 0,004, sehingga dapat disimpulkan bahwa tolak $\mathrm{H}_{0}$ dan terima $\mathrm{H}_{\mathrm{a}}$, artinya parameter tersebut signifikan secara statistic pada tingkat kesalahan $\alpha=$ 1\%. Serta pada Exp (B) menunjukkan nilai yang artinya bahwa peluang untuk beralih dari tanaman tembakau ke cabai yang dipengaruhi oleh variabel pendapatan 1,031 kali lebih besar peluangnya daripada peluang untuk tetap berusahatani tembakau. Nilai koefisien faktor pendapatan mempunyai tanda positif, artinya semakin besar pendapatan petani dalam berusahtani maka keputusan petani untuk beralih dari tanaman tembakau ke cabai semakin besar pula.

Berdasarkan fakta dilapangan petani yang melakukan alih fungsi lahan tembakau menjadi lahan cabai dipengaruhi oleh tingkat pendapatan antara usaha tani tembakau dan usahatani sengon. Hasil panen dan nilai jual dari tanaman cabai lebih tinggi dibandingkan hasil panen dan nilai jual tanaman tembakau, meskipun tanaman cabai membutuhkan waktu yang relatif lebih lama dibandingkan tembakau. Tapi keinginan petani untuk memperoleh pendapatan yang tinggi dari usahataninya menjadi pendorong untuk beralih ke sengon.

Dari 5 variabel pembentuk model peluang petani untuk beralih dari tanaman tembakau ke cabai hanya dua variabel yang tidak signifikan yakni variabel pengalaman berusahatani dan variable tingkat pendidikan petani.

Berdasarkan pemaparan diatas perilaku petani yang melakukan alih fungsi lahan tembakau menjadi lahan cabai dipengaruhi oleh beberapa faktor, diantaranya ialah faktor ekonomi (penghasilan) petani yang rendah dan faktor kondisi lahan, dimana lahan yang dimiliki petani tidak begitu luas dengan rata- rata luas lahan antara $50 \mathrm{~m}$ hingga 100 $\mathrm{m}$ dan faktor yang sangat berpengaruh terhadap perilaku petani ialah faktor pendapatan dari kedua komoditas tersebut, dimana keuntungan dari menanam cabai cukup besar dari pada menanam tembakau.

\section{KESIMPULAN DAN SARAN}

Kesimpulan yang dapat diambil sesuai dengan tujuan adalah faktor yang paling dominan yang mempengaruhi perilaku petani dalam alih fungsi lahan tembakau ke lahan cabai adalah 
pendapatan antara usaha tani tembakau dan usahatani cabai dengan signifikansi sebesar 0,004 pada tingkat kesalahan $\alpha=$ $1 \%$. Faktor berikutnya yang juga berpengaruh terhadap perilaku petani dalam alih fungsi lahan tembakau menjadi lahan cabai yaitu faktor ekonomi (penghasilan) keluarga dengan signifikansi sebesar 0,175 pada tingkat kesalahan $\alpha=$ $20 \%$, dan faktor kondisi lahan dengan signifikansi sebesar 0,005 pada tingkat kesalahan $\alpha=1 \%$. Jadi, dapat disimpulkan dalam penelitian ini ada tiga faktor yang berpengaruh terhadap perilaku petani dalam alih fungsi lahan tembakau menjadi lahan cabai yaitu faktor ekonomi, kondisi lahan dan pendapatan.

Disarankan kepada petani untuk melakukan alih komoditas dari tembakau ke usahatani cabai karena lebih menguntungkan meskipun biaya produksi lebih besar namun dapat mengurangi resiko gagal panen dan fluktuasi harga dan kepada pemerintah disarankan agar dapat memberikan bantuan modal atau pinjaman kepada petani yang ada di daerah penelitian dengan bunga yang rendah agar petani yang ingin melakukan usahatani memiliki modal yang cukup karena dalam usahatani memerlukan biaya produksi yang lebih banyak.

\section{DAFTAR PUSTAKA}

Gujarati, Damodar. 2010. Dasar-Dasar Ekonometrika. Jakarta: Erlangga.

Irawan, Bambang. 2005. Konversi Lahan Sawah Menimbulkan Dampak Negatif Bagi Ketahanan Pangan dan Lingkungan. Bogor. Pusat Analisis Sosial Ekonomi dan Kebijakan Pertanian.

Kustiawan, Iwan. 1997. Permasalahan Konversi Lahan Pertanian Dan Implikasinya Terhadap Penataan Ruang Wilayah. studi Kasus .
Wilayah Pantura Jawa Barat. Jurnal PWK. Vol. 8, No. 1/Januari 1997.

Lestari, T. 2009. Dampak Konversi Lahan Pertanian Bagi Taraf Hidup Petani. Skripsi. Bogor. Institut Pertanian Bogor.

Martawijaya. A, I. Kartasujana. 1977. Ciri Umum, Sifat dan Kegunaan JenisJenis Kayu Indonesia. Publikasi Khusus No. 41. LPHH, Bogor

Mubyarto. 1995. Pengantar Ekonomi Pertanian. Edisi ketiga

Najiyati S dan Danarti. 1999. Palawija, Budidaya dan Analisis Usaha Tani. Penebar Swadaya. Jakarta.

Notoatmodjo, Soekidjo. 2003. Pendidikan Dan Perilaku Kesehatan. Rineka Cipta. Jakarta.

Rahmat Rukmana, H. Ir. 1997. Ubi Kayu, Budidaya dan Pasca Panen. Penerbit Kanisius (Anggota IKAPI). Yogyakarta

Ritohadoyo Su. 2007. Perubahan Permukiman Perdesaan Pesisir. Universitas Gajah Mada. Yogyakarta.

Sihaloho. 2007. Konversi Lahan Pertanian dan Perubahan Struktur Agraria (Studi Kasus di Kelurahan Mulyaharaja, Kecamatan Bogor Selatan, Kota Bogor, Jawa barat). Sodality: Jurnal Transdisiplin Sosiologi, Komunikasi, dan Ekologi Manusia Vol. 1. Tahun 2007. Jawa Barat.

Soekartawi. 1995. Ilmu Usaha Tani Dan Penelitian Untuk Perkembangan Petani Kecil. Universitas Indonesia (UI-Press) Salemba 4. Jakarta. 